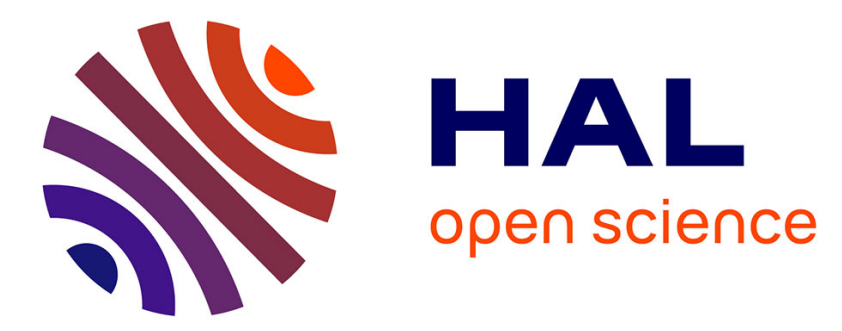

\title{
The Susceptibility of Local Parameters to Steel Microstructure Evaluated Using Charpy Type Specimen
}

\author{
I. Dlouhý, V. Kozák, L. Válka, M. Holzmann
}

\section{To cite this version:}

I. Dlouhý, V. Kozák, L. Válka, M. Holzmann. The Susceptibility of Local Parameters to Steel Microstructure Evaluated Using Charpy Type Specimen. Journal de Physique IV Proceedings, 1996, 06 (C6), pp.C6-205-C6-214. 10.1051/jp4:1996620 . jpa-00254448

\section{HAL Id: jpa-00254448 https://hal.science/jpa-00254448}

Submitted on 1 Jan 1996

HAL is a multi-disciplinary open access archive for the deposit and dissemination of scientific research documents, whether they are published or not. The documents may come from teaching and research institutions in France or abroad, or from public or private research centers.
L'archive ouverte pluridisciplinaire HAL, est destinée au dépôt et à la diffusion de documents scientifiques de niveau recherche, publiés ou non, émanant des établissements d'enseignement et de recherche français ou étrangers, des laboratoires publics ou privés. 


\title{
The Susceptibility of Local Parameters to Steel Microstructure Evaluated Using Charpy Type Specimen
}

\author{
I. Dlouhý, V. Kozák, L. Válka and M. Holzmann \\ Institute of Physics of Materials, Academy of Sciences of the Czech Republic, 61662 Brno, Czech Republic
}

\begin{abstract}
Accepting the Beremin approach to the analysis of cleavage failure criteria the local fracture parameters have been calculated using FEM for Charpy type specimen. Two types of model ferritic microstructures have been selected for presentation differing by carbide thickness and scatter of fracture toughness data. For the microstructures investigated the Weibull stresses (location parameters) were related to cleavage fracture stresses determined supposing deterministic nature of cleavage fracture events at initiation. The results of static three point bending and low blow impact testing were used for these purposes. Microstnuctural and microfractographic reasons for scatter of data were determined. Relation of microstructural and microfractographic features to local fracture criteria was analysed.
\end{abstract}

\section{INTRODUCTION}

The origin of brittle fracture initiation in structural ferritic steels is frequently associated with cleavage of ferritic (sub)grains often induced by brittle particle (carbide) or inclusion. The nucleating event of macroscopic cleavage initiation follows from successive occurrence of several simple phenomena [1-3]: (i) slip induced cleavage separation of ferrite grain, (ii) carbide cracking inside or at grain boundary, and (iii) transmission of microcrack on cleavage plane of the neighbouring grain across the (sub)grain boundary. Cleavage fracture stress was introduced which is a local material parameter characterising the microscopic resistance of the given microstructure against cleavage failure [4]. Based on this concept the initiation of the brittle fracture occurs when the local maximum principal stress, $\sigma_{1}{ }^{\max }$, is higher than the cleavage fracture stress. To determine the critical state of component with flaw according to this deterministic approach, the elastic-plastic solution of stress state ahead of the notch or crack tip must be carried out. For ferritic steels it was shown that the cleavage fracture stress plays a controlling role in the cleavage fracture initiation of notched and/or precracked specimens [4,5]. Macroscopically, this stress was proved to be independent of temperature and hydrostatic stress [1]. Microscopically, the value of the cleavage fracture stress is strongly affected by microstructure [8,9]. The physical events involved in the cleavage fracture have been well understood and a range of quantitative relation [8-13] was proved.

Statistical model have been developed [14] in which the cleavage fracture characteristics are related to the distribution of brittle particles, involving a statistical competition between different sized crack nuclei in the rapidly changing stress gradient ahead of the crack tip. Some of the microstructural features and events preceding the fracture initiation have statistical nature. Firstly, the causes can be seen in stochastic nature of cleavage separation itself [2]. Secondly, in case of carbide controlled cleavage the parameters of the particles distributions directly govern fracture micromechanism [14-18]. Thirdly, some uncertainty in exact description of real microstructure still exists, it is associated with random inhomogeneities in microstructural features and with local differences in stress - strain state below the defect [18]. While in the deterministic concept the initiation location is pre-determined by a site of local maximum stress, in the latter the cleavage microcracks should form in a small volume located in any place in the plastic zone ahead of crack tip. The physically based calculation procedures may be developed enabling the cleavage fracture toughness to determine from the carbide thickness and/or other microstructural parameters distribution [15-20]. 
As shown [21] brittle failure probability of arbitrary cell inside the process zone is controlled by applied stress $\sigma, P_{f}=\left(\sigma / \sigma_{u}\right)^{\mathrm{m}}$; where $\mathrm{m}$ is Weibull shape parameter characterising scatter, and $\sigma_{\mathrm{u}}$ is Weibull location parameter, a stress which represents the intrinsic resistance of the material to cleavage fracture. Cumulative probability of failure can be found introducing the Weibull stress into the above equation, $P_{\mathrm{f}}=1-\exp \left\{-\left(\sigma_{\mathrm{w}} / \sigma_{\mathrm{u}}\right)^{\mathrm{m}}\right\}$. The stress $\sigma_{\mathrm{w}}$ is given [21] by expression $\sigma_{\mathrm{w}}=\left\{\Sigma \sigma_{1}^{\mathrm{m}}\left(\Delta \mathrm{V} / \mathrm{V}_{0}\right)\right\}^{1 / \mathrm{m}}$. $\Delta \mathrm{V}$ is a volume in which the principal stress $\sigma_{1}$ is acting and it is usually determined by the corresponding finite mesh element used by FEM. The integration is evaluated over plastically deformed elements on premise that microcracks are not created in the cells residing outside the crack-tip plastic zone. The cell volume $\mathrm{V}_{0}$ can be chosen in the order of about ten grain sizes in case the brittle fracture micromechanism is dominating [22]. Parameters $\sigma_{u}$ and $\mathrm{m}$ are considered to be transferable local material properties, independent of temperature, geometry or loading mode. The statistical models [e.g. $21,24,26]$ resulted in reasonable prediction of temperature dependence of fracture toughness and its scatter. The continuum view in these statistic approaches still cannot provide any further physical insight into the fracture process, however. Microstructural aspects in relation to parameters $\sigma_{u}$ and $m$ need further explanation and/or quantification. Relatively small attention has been paid to the CVN bend specimen from this point of view although complication might be supposed due to sharp stress gradient below V notch [28].

The aim of the paper can be seen in experimental verification of the microstructural nature of cleavage fracture stress and location parameter for two different model microstructures. The independence of cleavage fracture stress on temperature and strain rate should be also proved. The susceptibility of local parameters to steel microstructure should be also discussed.

\section{MATERIAL AND EXPERIMENTAL PROCEDURES}

\subsection{Material characteristics}

A CrMoV rotor steel has been utilized for experiments having chemical composition (in wt. \%): $0.23 \mathrm{C}, 0.64$ $\mathrm{Mn}, 0.28 \mathrm{Si}, 0.022 \mathrm{P}, 0.028 \mathrm{~S}, 1.23 \mathrm{Cr}, 0.55 \mathrm{Mo}, 0.16 \mathrm{~V}$. The steel was commercially produced as hot rolled bars having section $30 \times 60 \mathrm{~mm}^{2}$. A range of microstructures has been tested to study the upper nose temper embrittlement phenomena [29,30]. Two model microstructures were selected for this investigation: (i) ferrite with fine carbides (bainite - normalized from $940^{\circ} \mathrm{C}$, then tempered for $2 \mathrm{~h}$ at $680^{\circ} \mathrm{C}$ ) and (ii) ferrite with coarser carbides (bainite - tempered for $10 \mathrm{~h}$ at $720^{\circ} \mathrm{C}$ after normalization). Selected materials characteristics are shown in Table 1. In this table, the value of $d_{A G}$ represents prior austenitic grain size, $d_{p}$ is packet size, $d_{c}$ is mean value of carbide size, $d_{c}(c)$ represents the $95 \%$ percentile of carbide diameter distribution measured.

Table 1: Microstructural and selected mechanical characteristics of materials studied (FC - ferritic matrix with fine carbides, CC ferritic matrix with coarse carbides)

\begin{tabular}{|l|l|c|c|c|c|c|c|c|c|c|}
\hline $\begin{array}{l}\text { micro- } \\
\text { structure }\end{array}$ & tempering & $\mathrm{HV} 10$ & $\begin{array}{c}\mathrm{d}_{\mathrm{AG}} \\
{[\mu \mathrm{m}]}\end{array}$ & $\begin{array}{c}\mathrm{d}_{\mathrm{p}} \\
{[\mu \mathrm{m}]}\end{array}$ & $\begin{array}{c}\mathrm{d}_{\mathrm{c}} \\
{[\mu \mathrm{m}]}\end{array}$ & $\begin{array}{c}\mathrm{d}_{\mathrm{c}}(\mathrm{c}) \\
{[\mu \mathrm{m}]}\end{array}$ & $\begin{array}{c}\mathrm{R}_{\mathrm{p}} 0.2 \\
{[\mathrm{MPa}]}\end{array}$ & $\begin{array}{c}\mathrm{R}_{\mathrm{m}} \\
{[\mathrm{MPa}]}\end{array}$ & $\begin{array}{c}\text { CVN imp. } \\
\text { energy }[\mathrm{J}]\end{array}$ & $\begin{array}{c}\text { FATT } \\
{\left[{ }^{\circ} \mathrm{C}\right]}\end{array}$ \\
\hline FC & $680^{\circ} \mathrm{C} / 2 \mathrm{~h} / \mathrm{AC}$ & 278 & 29 & 15 & 0.09 & 0.33 & 771 & 886 & 18 & 110 \\
\hline $\mathbf{C C}$ & $720^{\circ} \mathrm{C} / 10 \mathrm{~h} / \mathrm{AC}$ & 200 & 29 & 12 & 0.17 & 0.47 & 511 & 644 & 51 & 50 \\
\hline
\end{tabular}

\subsection{Mechanical testing}

The yield strength and true stress-strain curves have been measured using cylindrical specimens with diameter of $6 \mathrm{~mm}$ being loaded over temperature range of -196 to $+200^{\circ} \mathrm{C}$ at cross - head speed of $2 \mathrm{~mm}$. min ${ }^{-1}$. The yield strength was taken to be the lower yield stress value $\left(R_{\mathrm{eL}}\right)$ or the $0.2 \%$ proof stress $\left(R_{p} 0.2\right)$.

Temperature dependencies of fracture toughness have been measured using $25 \mathrm{~mm}$ thick specimen loaded in three point bending at cross head speed of $1 \mathrm{~mm} . \mathrm{min}^{-1}$.

Charpy type specimens were tested under the three types of loading (strain rates): (i) Temperature dependencies of CVN impact energy were measured using standard impact tester. The testing was carried out over a temperature range of -196 to $200^{\circ} \mathrm{C}$ and fracture appearance transition temperatures (FATT) have been determined among others. (ii) To evaluate the cleavage fracture stress, $\sigma_{\mathrm{CF}}$, the Charpy type specimens were 
dynamically loaded on instrumented impact tester with lowered hammer drop rate of $1.5 \mathrm{~ms}^{-1}$ (low blow method). Load - displacement traces have been recorded, and the maximum force, $F_{\mathrm{M}}$, fracture force, $F_{\mathrm{FR}}$, and general yield force, $\mathrm{F}_{\mathrm{GY}}$, respectively have been taken from records. (iii) The same methodological approaches and Charpy type specimen in three point bending were used for determination of cleavage fracture stress under static condition of loading. For one selected temperature in lower shelf region (below $t_{\mathrm{GY}}-$ see later) a range of bend tests was performed to obtain data for statistical treatment for both microstructures tested.

Axisymmetrically notched tensile specimens with diameter of $16 \mathrm{~mm}$ were also tested to generate data for local parameter calculation. The Charpy type geometry of the notch was machined circumferencially, the minimum specimen diameter in notch root section being $10 \mathrm{~mm}$.

\subsection{Fractography and supporting procedures}

For CVN specimen tested around and below the brittleness transition temperature, $\mathrm{t}_{\mathrm{GY}}$, the distances between the fracture initiation sites and the notch root were evaluated using SEM micrographs. The mean caliper diameter of facets projected into micrograph plane was taken as the facet size, micrographs were taken in the vicinity of initiation sites at magnification about 2000 times. Data were compared with similar dimensions measured in metallographic section perpendicularly to fracture surface [30]. To identify the microstructural causes of cleavage facet nucleation the triggering origins of facets in failure initiation sites were assessed.

To determine all necessary microstructural parameters the microstructures were assessed using scanning electron microscopy, thin foils and carbide extraction replicas were examined using transmission electron microscopy $[29,30]$.

\section{CALCULATION PROCEDURES}

For test temperature below $t_{\mathrm{GY}}$ (see table 2) the principal stress distributions below the notch were calculated. A 2D model under plane strain conditions was used for the elastic-plastic analysis using symmetry of the three point bending of V-notched specimen [31]. True stress - true strain curves were approximated using bilinear parameters $\left(\sigma_{\mathrm{y}}\right.$ and $\mathrm{E}_{\mathrm{t}}$ shown in table 2$)$. Finite elements package ANSYS 5.1 was used for calculations.

Table 2: Experimental material characteristics and data used in FEM calculations

\begin{tabular}{|l|c|c|c|c|c|c|c|}
\hline & test temp. $\left[{ }^{\circ} \mathrm{C}\right]$ & $\mathrm{R}_{\mathrm{p}} 0.2[\mathrm{MPa}]$ & $\mathrm{R}_{\mathrm{m}}[\mathrm{MPa}]$ & $\mathrm{E}[\mathrm{MPa}]$ & $\sigma_{\mathrm{v}}[\mathrm{MPa}]$ & $\mathrm{E}_{\mathrm{t}}[\mathrm{MPa}]$ & $v$ \\
\hline $\mathbf{F C}$ & -80 & 868 & 980 & $2.05 \mathrm{e} 5$ & 960 & $1.05 \mathrm{e} 4$ & 0.3 \\
\hline $\mathbf{C C}$ & -150 & 729 & 845 & $2.05 \mathrm{e} 5$ & 814 & $1.10 \mathrm{e} 4$ & 0.3 \\
\hline
\end{tabular}

Accepting the Beremin approach to the analysis of local criterion for cleavage fracture the location parameters for Charpy type specimen were calculated. The flow behaviour was computed using incremental plasticity (with Von Mises criterion). The attention was paid to the implementation of the true stress - true strain curve. To prove the validity of FEM calculation for CVN and notched tensile specimen the load - displacement dependencies were computed and compared with the experimentally obtained traces. Standard finite element computer code for strain and stress distribution around the notch was used. Then the Weibull shape parameter, $\mathrm{m}$, and Weibull stress, $\sigma_{\mathrm{w}}$, were determined by integration in the plastic zone ahead of the crack tip for estimated values of characteristic cell $V_{0}$. From the plot of calculated probability vs $\sigma_{\mathrm{w}}$ the Weibull parameter $\mathrm{m}$ can be modified. Once the value of $\mathrm{m}$ has been determined, the value of location parameter, $\sigma_{u}$, is read from the linear regression for $P_{f}=0.63$. Similar procedure was applied for determination of local parameters for notched tensile specimens.

\section{RESULTS DESCRIPTION}

\subsection{Fracture behaviour of CVN and precracked bend specimen}

The temperature dependencies of fracture toughness are shown in Fig. 1a, b. In order to determine the scatter band of fracture toughness values in lower shelf regime a number of specimens was tested at one 
temperature and data obtained are also given in Fig. 1, commonly with scatter parameter $\mathrm{m}$. The dashed lines represent the $90 \%$ probability scatter band of all values in transition region. The comparison of both figures, 1a) and 1b), shows that except for shift of transition region up to lower temperatures, the scatter in fracture toughness values decreases with increase in average carbide diameter. Ductile tearing preceding cleavage was determined fractographically and is indicated by symbols $\mathrm{K}_{\mathfrak{j} \mathbf{u}}$ and $\mathrm{K}_{\mathrm{Jm}}$ in figures.
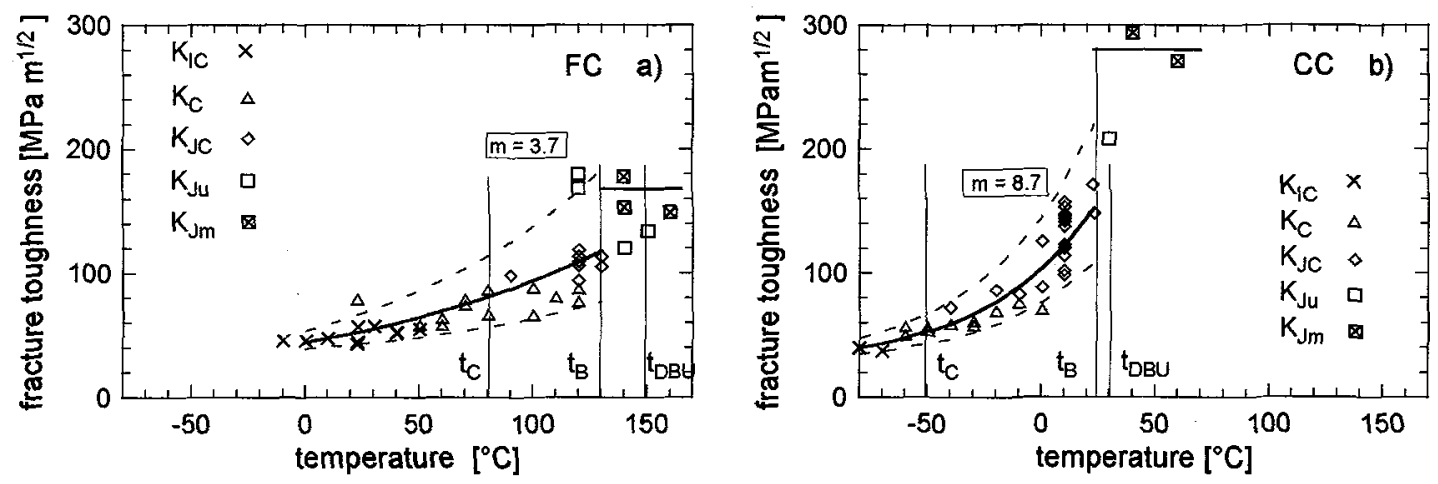

Figure 1: Temperature dependencies of fracture toughness for microstructure with fine carbides (FC, slightly tempered) - a), and for ferrite with coarse carbides (CC, heavy tempered) - b).
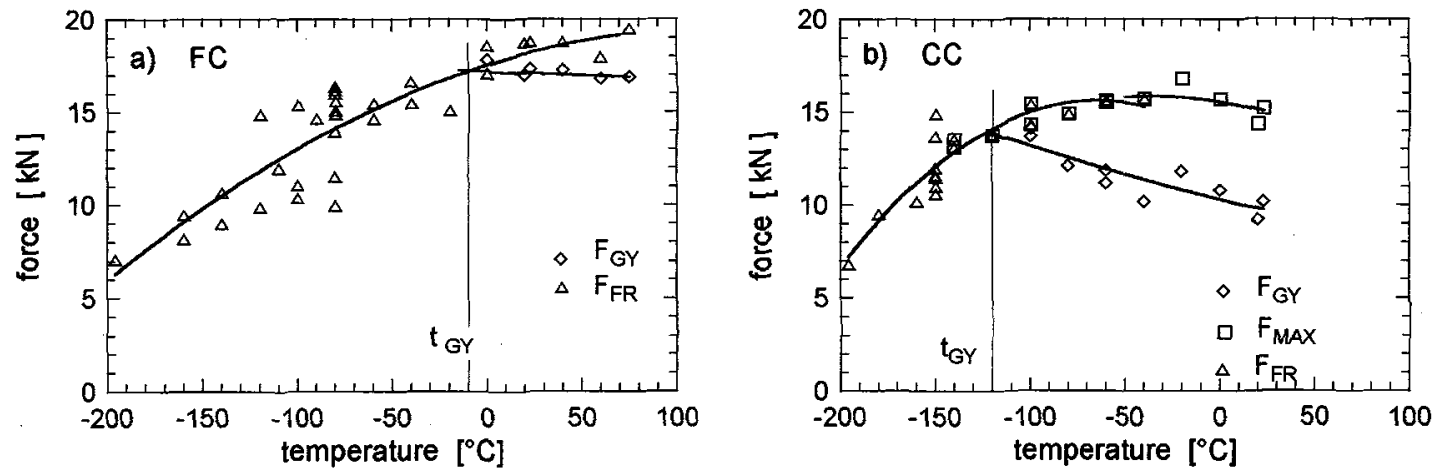

Figure 2: Temperature dependencies of characteristic forces obtained from load-displacement traces of CVN specimen loaded in static bending.

Temperature dependencies of general yield force, $\mathrm{F}_{\mathrm{GY}}$, fracture force, $\mathrm{F}_{\mathrm{FR}}$, and maximum force $F_{\text {MAX }}$, obtained from statically loaded CVN specimens, are shown in Fig. 2a, b. Similar dependencies were obtained for instrumented impact testing [28,32]. Two significant results can be drawn from comparison of both plots in Fig. 2: the lower brittleness transition temperature, $t_{G Y}$, and comparably lower general yield force, $F_{G Y}$, at this temperature are observed for the microstructure with coarse carbides. The above mentioned findings correspond well to upper nose temper embrittlement phenomena analysed elsewhere [33] and are well supported by fractographic observations of bend specimens:

At lower magnification (Fig. 3 and 4), the fracture surfaces of CVN bend specimen (and similarly of precracked bend specimen) exhibited macroscopic river patterns. For the microstructure with fine carbides (FC) this pattern originates at one small spot in the fracture surface (see Fig. 3b) which contains one or a few cleavage facets. For microstructure with coarse carbides $(\mathrm{CC})$ the river patterns are traced to initiation region (band) of width designated as $\Delta r$ in Fig. $4 a$. In both cases the center of the river pattern was assumed to be the cleavage initiation origin.

At higher magnification (SEM), four types of initiation origins were identified:

(i) One cleavage facet without distinct triggering point, typical for FC state. Average size of the individual facets was about 20 to $30 \mu \mathrm{m}$. Dislocation micromechanisms of cleavage was supposed in these cases. 
(ii) Two or three cleavage facets arranged in initiation site (Fig. 5a), all facets without clear triggering point. Cleavage starting from grain boundaries or triple points was supposed in these cases.

(iii) Facets with one large or with a few smaller inclusion located on the middle of the facet.

(iv) Cleavage facet with carbide particles (Fig. 5b, increased metal content in particles in comparison to matrix has been proved by microanalysis). Carbide mechanism of cleavage triggering was supposed in these cases which were observed essentially in heavy tempered microstructures (CC).
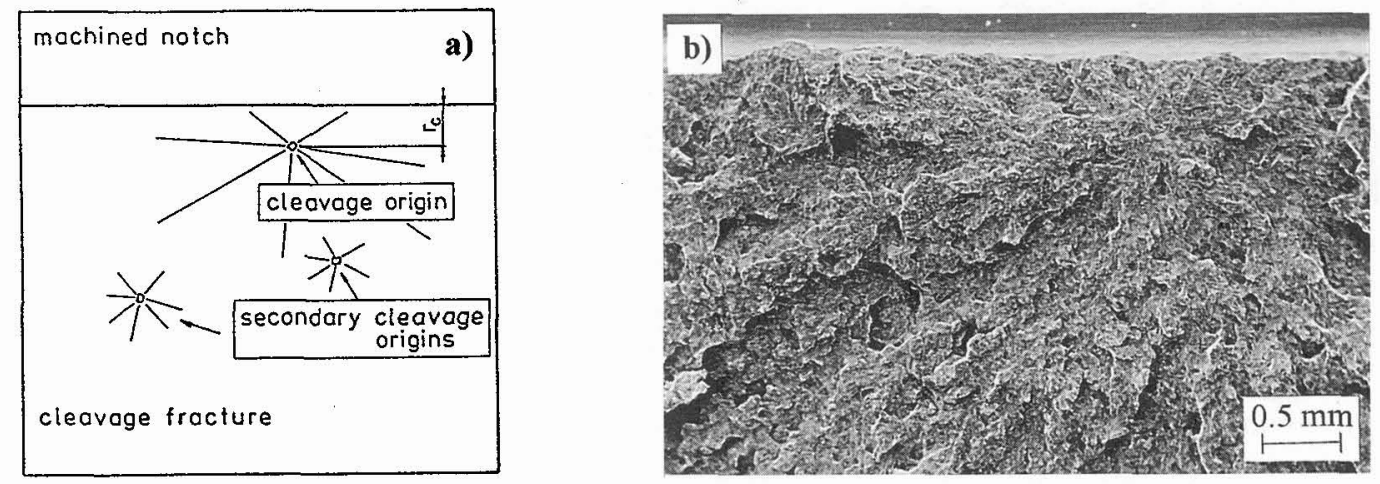

Figure 3: Fracture appearance of CVN specimens tested at $-80^{\circ} \mathrm{C}$ for microstructure with fine carbides (FC)
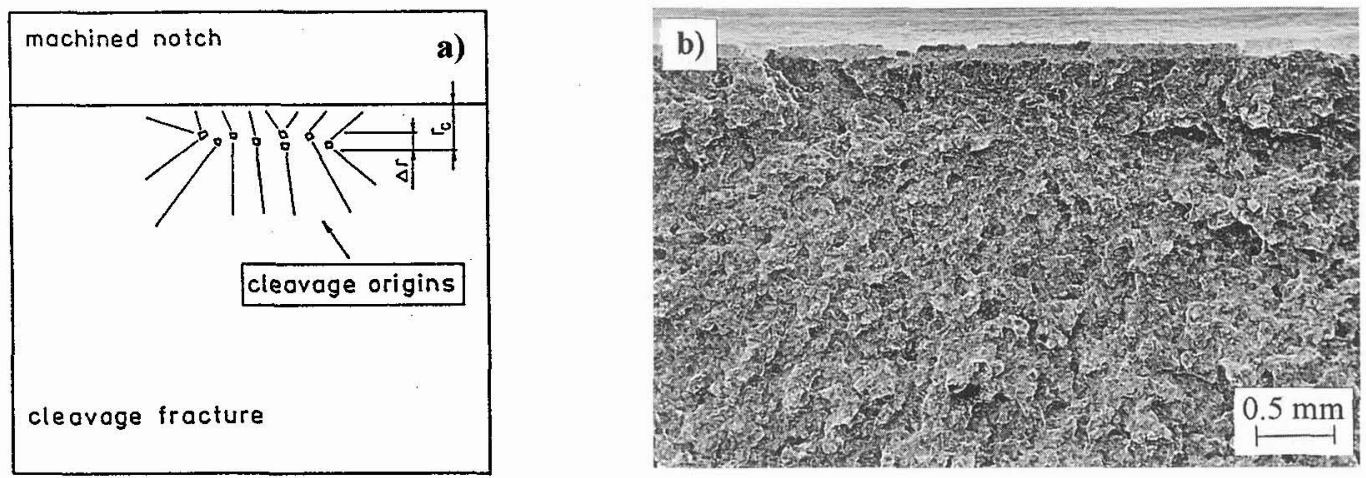

Figure 4: Fracture appearance of $\mathrm{CVN}$ specimens tested at $-150^{\circ} \mathrm{C}$ for microstructure with coarse carbides (CC)

With increase of carbide diameter the substantial changes in cleavage micromechanism and macroscopic appearance of fracture surface were thus observed. The fracture appearance changes from morphology with single initiation site to this one with more multiple initiation sites. Dislocation micromechanism of cleavage triggering was supposed for microstructure with fine carbides, while almost carbide origin of cleavage was observed for microstructures with coarse carbides. Supposing all known cleavage nucleation micromechanisms (dislocation, inclusion, grain triple point assistance, carbide) the number of individual micromechanisms identified in initiation sites of bend specimens are summarized in Table 3 for increasing carbide thickness.

Table 3: Quantitative fraction of individual triggering mechanism in dependence on carbide thickness (i.e. on tempering)

\begin{tabular}{|c|c|c|c|c|c|c|c|c|}
\hline \multirow{2}{*}{\multicolumn{2}{|c|}{$\begin{array}{cl}\text { triggering - labelled } \\
\text { by }\end{array}$}} & \multicolumn{7}{|c|}{ average carbide diameter $[\mu \mathrm{m}]$} \\
\hline & & 0.07 & 0.08 & $0.09(\mathrm{FC})$ & 0.12 & 0.15 & $0.17(\mathrm{CC})$ & 0.21 \\
\hline carbide & $\mathrm{C}$ & - & - & $=$ & - & 2 & 6 & 5 \\
\hline inclusion & I & - & - & 1 & - & - & 2 & - \\
\hline triple point & $\mathrm{B}$ & 4 & 3 & 3 & 3 & 2 & 1 & 1 \\
\hline dislocation & $\mathrm{D}$ & 3 & 4 & 5 & 4 & 3 & - & - \\
\hline
\end{tabular}



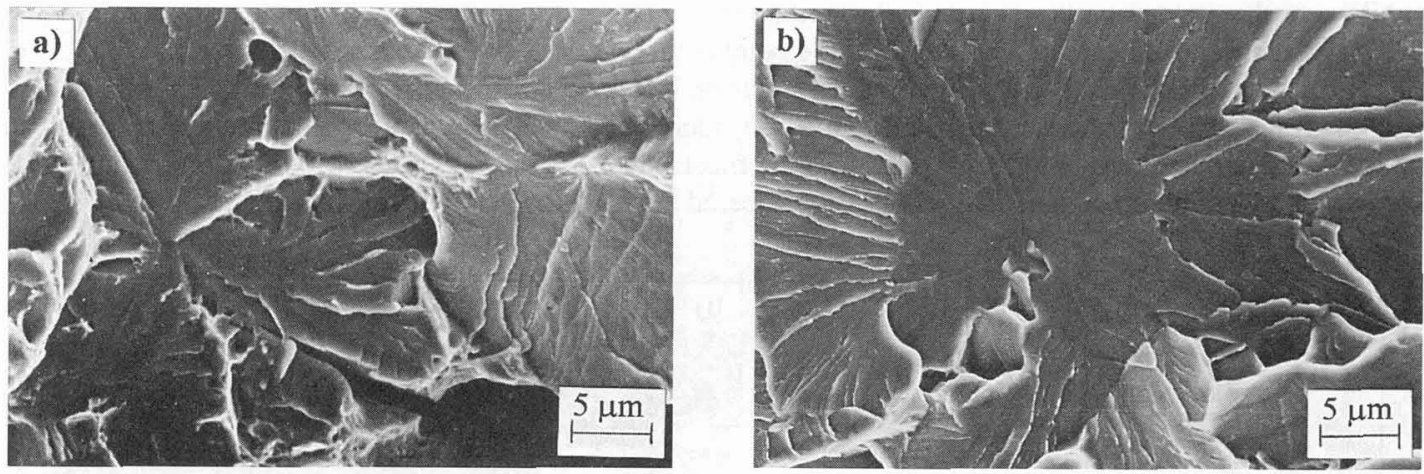

Figure 5: Micrographs of fracture initiating cleavage facets a) for FC microstructure and b) for CC microstructure

The fracture behaviour of FC microstructure corresponds to weakest link sites concept. Activating one weak link causes unstable fracture. The governing fracture mechanisms in CC microstructure fit well to concept of critical damage sites. Activating one critical damage site does not cause unstable cleavage failure, rather a critical number of these sites must be activated in order to get cleavage.

\subsection{Cleavage fracture stress}

To determine the cleavage fracture stress experimentally two procedures were used:

(i) For CVN specimens loaded statically and by low blow technique, the cleavage fracture stress was take evaluated as local maximum tensile stress ahead of the notch at fracture. At temperatures where fracture and general yield force were coincident (i.e. at brittleness transition temperatures $t_{\mathrm{GY}}$ ) the same procedure of local maximum tensile stress calculation for CVN specimen as used by Brozzo et al. [11] was applied. The value of 2,24 of plastic stress concentration factor of $k_{\text {op. }}$ was taken. The relation of measured static and dynamic yield strength and general yield force was determined and the results are given elsewhere [34]. Arising from the linear relation of static and/or dynamic yield strength $\sigma_{\mathrm{y}}, \sigma_{\mathrm{y}}{ }^{\mathrm{d}}$ and general yield force $\mathrm{F}_{\mathrm{GY}}, \mathrm{F}_{\mathrm{GY}}{ }^{\mathrm{d}}$ the simplified approach could be used for calculation of $\sigma_{\mathrm{CF}}$ from general yielding force at $\mathrm{t}_{\mathrm{Bv}}$, thus, $\sigma_{\mathrm{CF}}=106$. $\mathrm{F}_{\mathrm{GY}}$.

(ii) For a range of CVN specimens tested statically in bending at one selected temperature the tensile stress distribution below the $\mathrm{V}$ notch has been calculated using FEM. The distances between the initiation origin (site) and the notch root were measured from SEM micrographs. These distances, $r_{c}$, have been used to obtain the local tensile fracture stress from maximum principal stress distribution corresponding to fracture. The results of the measurement and local stresses determination are shown in Tables $\mathbf{4}$ and 5 .

Table 4: Initial data and local cleavage stress values for $\mathrm{CVN}$ bend specimen tested at $-80^{\circ} \mathrm{C}$; $\mathrm{FC}$ microstructure

\begin{tabular}{|c|c|c|c|c|c|c|c|c|c|}
\hline $\begin{array}{c}\text { spec. } \\
\text { numb. }\end{array}$ & $\begin{array}{c}\mathrm{F}_{\mathrm{FR}} \\
{[\mathrm{kN}]}\end{array}$ & $\begin{array}{c}\mathrm{r}_{\mathrm{c}} \\
{[\mathrm{mm}]}\end{array}$ & $\begin{array}{c}\Delta \mathrm{r} \\
{[\mathrm{mm}]}\end{array}$ & $\begin{array}{c}\sigma_{\mathrm{CF}}{ }^{*} \\
{[\mathrm{MPa}]}\end{array}$ & $\begin{array}{c}\sigma_{\mathrm{CF}}{ }^{*}(\Delta \mathrm{r}) \\
{[\mathrm{MPa}]}\end{array}$ & $\begin{array}{c}\sigma_{\mathrm{CF}} \pm \text { st.dev } \\
{[\mathrm{MPa}]}\end{array}$ & $\begin{array}{c}\text { triggering } \\
\text { sites }\end{array}$ & $\begin{array}{c}\sigma_{\mathrm{CF}}(\mathrm{st}) \\
{[\mathrm{MPa}]}\end{array}$ & $\begin{array}{c}\sigma_{\mathrm{CF}}(\mathrm{dyn}) \\
{[\mathrm{MPa}]}\end{array}$ \\
\hline 45 & 14.7 & 0.47 & 0 & 1991 & & $2033 \pm 44$ & $\mathrm{~B}$ & 1972 & 2003 \\
\hline 26 & 12.5 & 0.37 & 0 & 1982 & & & $\mathrm{~B}$ & & \\
\hline 43 & 11.6 & 0.30 & 0 & 1985 & & & $\mathrm{I}$ & & \\
\hline 27 & 13.5 & 0.35 & 0 & 2045 & & & $\mathrm{D}$ & & \\
\hline 25 & 15.6 & 0.41 & 0 & 2089 & & & $\mathrm{D}$ & & \\
\hline 23 & 16.4 & 0.43 & 0 & 2098 & & & $\mathrm{D}$ & & \\
\hline 36 & 14.9 & 0.47 & 0 & 2013 & & & $\mathrm{~B}$ & & \\
\hline 22 & 12.5 & 0.29 & 0 & 2027 & & & $\mathrm{D}$ & & \\
\hline 20 & 16 & 0.45 & 0 & 2067 & & & $\mathrm{D}$ & & \\
\hline
\end{tabular}

Due to multiple initiation characterised in Fig. 5a by initiation band width, $\Delta \mathrm{r}$, two values of distances between notch root and initiation region were necessary to apply. The lower value of local cleavage stress corresponds to deepest measurable dimension observed. The higher stress values labelled as $\sigma_{\mathrm{CF}}^{*}(\Delta \mathrm{r})$ correspond to lowest depth observed. 
Table 5: Details of local cleavage stress determination for $\mathrm{CVN}$ bend specimen tested at $-150^{\circ} \mathrm{C}, \mathrm{CC}$ microstructure

\begin{tabular}{|c|c|c|c|c|c|c|c|c|c|}
\hline $\begin{array}{c}\text { spec. } \\
\text { numb. }\end{array}$ & $\begin{array}{c}\mathrm{F}_{\mathrm{FR}} \\
{[\mathrm{kN}]}\end{array}$ & $\begin{array}{c}\mathrm{r}_{\mathrm{c}} \\
{[\mathrm{mm}]}\end{array}$ & $\begin{array}{c}\Delta \mathrm{r} \\
{[\mathrm{mm}]}\end{array}$ & $\begin{array}{c}\sigma_{\mathrm{CF}}^{*} \\
{[\mathrm{MPa}]}\end{array}$ & $\begin{array}{c}\sigma_{\mathrm{CF}}^{*}(\Delta \mathrm{r}) \\
{[\mathrm{MPa}]}\end{array}$ & $\begin{array}{c}\sigma_{\mathrm{CF}} \pm \mathrm{st.dev} . \\
{[\mathrm{MPa}]}\end{array}$ & $\begin{array}{c}\text { triggering } \\
\text { sites }\end{array}$ & $\begin{array}{c}\sigma_{\mathrm{CF}}(\mathrm{st}) \\
{[\mathrm{MPa}]}\end{array}$ & $\begin{array}{c}\sigma_{\mathrm{CF}} \text { (dyn) } \\
{[\mathrm{MPa}]}\end{array}$ \\
\hline 9 & 14.4 & 0.35 & & 1830 & & $1585 \pm 54$ & $\mathrm{~B}$ & 1505 & 1569 \\
\hline 8 & 12.0 & 0.61 & 0.20 & 1531 & 1725 & & $\mathrm{C}$ & & \\
\hline 10 & 11.6 & 0.50 & 0.21 & 1615 & 1761 & & $\mathrm{C}$ & & \\
\hline 12 & 13.7 & 0.56 & 0.15 & 1628 & 1774 & & $\mathrm{C}$ & & \\
\hline 11 & 14.9 & 0.54 & 0.20 & 1612 & 1845 & & $\mathrm{C}$ & & \\
\hline 13 & 13.3 & 0.52 & 0.17 & 1651 & 1795 & & $\mathrm{I}$ & & \\
\hline 15 & 13.7 & 0.52 & 0.16 & 1615 & 1805 & & $\mathrm{C}$ & & \\
\hline 34 & 10.2 & 0.51 & 0.15 & 1507 & 1680 & & $\mathrm{C}$ & & \\
\hline 7 & 13.1 & 0.62 & 0.17 & 1526 & 1702 & & $\mathrm{I}$ & & \\
\hline
\end{tabular}

Comparison of cleavage fracture stress values obtained by different ways is possible using plots in Fig. 6 (data for CVN bend specimens loaded either statically or dynamically by low blow technique and local stresses determined from stress distributions below notch root for statically loaded specimen). For FC microstructure very good agreement of data was found and independence of cleavage fracture stress on temperature and strain rate was proved. Estimation of local cleavage stress for CC microstructure is associated with small uncertainty of exact localisation of initiation origin, although the lower values (obtained for $\left.r_{c}-\Delta r\right)$ correspond well to data calculated from general yield force.

The susceptibility of cleavage (local) fracture stress to microstructural differences is the most important results from above observation. From the current theories for cleavage fracture, an equation derived by Petch [9] (for cleavage fracture stress and carbide thickness) was found to give the most satisfactory agreement with our experimental

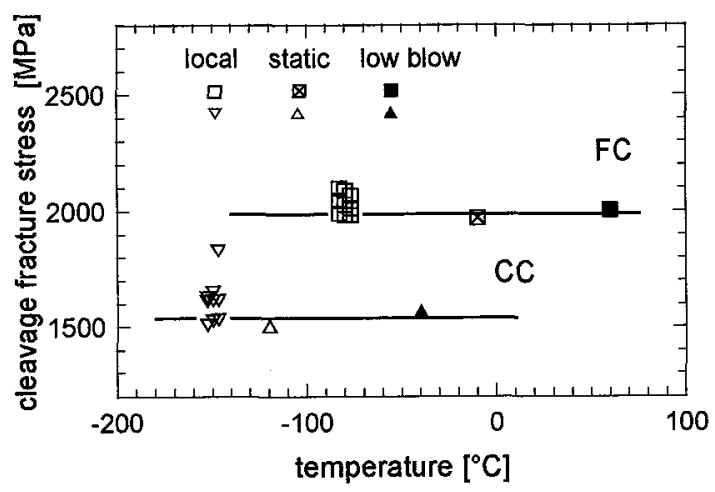
data for microstructure with coarse carbides.

\subsection{Local material parameters}

Based on the experimental results generated on nine Charpy V-notch specimens for both the FC microstructure (tested at $-80^{\circ} \mathrm{C}$ ) and the $\mathrm{CC}$ microstructure (tested at $-150^{\circ} \mathrm{C}$ ) the local parameters, $\sigma_{\mathrm{u}}$ and $\mathrm{m}$, were calculated. The results of calculation for various cell size, $\mathrm{V}_{0}$, are given in table 6 , the cell size is represented by parameter $\lambda$, according to equation $\lambda=\left(\mathrm{V}_{0}\right)^{1 / 3}$.

Using parameters given in table 6 the dependencies of cumulative probability on Weibull stress $\sigma_{\mathrm{w}}$ have been plotted for both microstructures investigated (Fig. 7a., 7b).

Table 6: Local parameters calculated for various cell sizes (parameter $\lambda$ is given by eq. $\lambda=\left(V_{0}\right)^{1 / 3}$ ) for CVN bend specimen

\begin{tabular}{|c|c|c|c|c|c|c|c|c|}
\hline \multirow{2}{*}{$\begin{array}{l}\text { micro- } \\
\text { structure }\end{array}$} & \multicolumn{2}{|c|}{$\lambda=50 \mu \mathrm{m}$} & \multicolumn{2}{c|}{$\lambda=\mathbf{7 5} \mu \mathrm{m}$} & \multicolumn{2}{c|}{$\lambda=100 \mu \mathrm{m}$} & \multicolumn{2}{c|}{$\lambda=125 \mu \mathrm{m}$} \\
\cline { 2 - 9 } & $\mathrm{m}$ & $\sigma_{u}[\mathrm{MPa}]$ & $\mathrm{m}$ & $\sigma_{u}[\mathrm{MPa}]$ & $\mathrm{m}$ & $\sigma_{\mathrm{u}}[\mathrm{MPa}]$ & $\mathrm{m}$ & $\sigma_{\mathrm{u}}[\mathrm{MPa}]$ \\
\hline $\mathrm{FC}$ & 12.52 & 4500 & 12.57 & 4081 & 12.56 & 3809 & - & - \\
\hline $\mathrm{CC}$ & 14.20 & 3450 & - & - & 14.38 & 3015 & 14.46 & 2875 \\
\hline
\end{tabular}

Allowing for the variation of location parameter, $\sigma_{\mathrm{u}}$, with cell size, $\mathrm{V}_{0}$, and the shape of cumulative probability curve (Fig.7), the following findings can be summarised: 

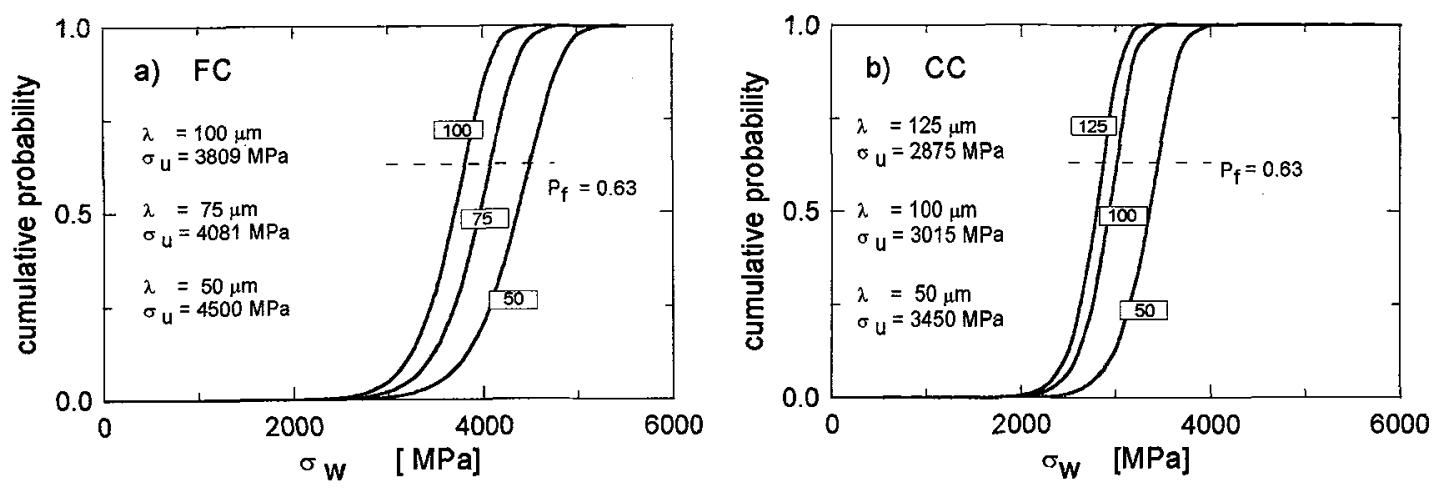

Figure 7: Cumulative probability of Weibull stress as a function of cell size and microstructure: a) for FC microstructure and b) for $\mathrm{CC}$ microstructure

- The local parameters $\sigma_{\mathrm{u}}$ and $\mathrm{m}$ are well susceptible to differences between the particular microstructures.

- FC microstructure exhibits comparably higher values of $\sigma_{\mathrm{u}}$ compared to the CC one, this fact is being in consistency with the values of cleavage fracture stresses $\sigma_{\mathrm{CF}}$ evaluated using the deterministic approach. Taking into account the real fracture toughness values (Fig. 1) the values of $\sigma_{\mathrm{u}}$ are susceptible to fracture micromechanism rather than to global toughness characteristics.

- Location parameter $\sigma_{u}$ is a strong function of cell size $V_{0}$ chosen. The drop of $\sigma_{u}$ with increasing of $V_{0}$ is approximately the same for both types of microstructures. It follows that for the assessment of structure with defects, the value of $V_{0}$ must be carefully chosen, with respect to the micromechanisms controlling the cleavage nucleation and transmission of microcrack within the elementary cell. For the microstructure with fine carbides $(\mathrm{FC})$, the dimension of cell $\lambda=\left(\mathrm{V}_{0}\right)^{1 / 3} \approx 50 \mu \mathrm{m}$ corresponding to sizes of two to three initiating cleavage facets is assumed to involve just this controlling initiation micromechanism. For microstructure with coarse carbides (CC), according to fractographic observation the dimension of cell volume $\left(\mathrm{V}_{0}\right)^{1 / 3} \approx 100$ to $125 \mu \mathrm{m}$ covering up ten initiating cleavage sites seems to be more appropriate.

- The above mentioned results indicate that the shape parameter $m$ is not dependent on the cell size $V_{0}$ chosen. These findings are valid for both microstructures and are in consistency with scatter of fracture toughness data. Comparing the Weibull shape parameter it may be seen that the microstructure with coarse carbides exhibits higher values of this parameters corresponding to the smaller scatter. At lower values of location parameter $\sigma_{\mathrm{u}}$ this means that the probability of cleavage failure initiation in the elementary cells is higher than in the cells microstructure with fine carbides. This probability enhancement should be associated with high carbide thickness and due to this carbide induced cleavage.

In order to test the reliability of determined local parameters the comparison of predicted fracture toughness - temperature diagrams (including scatter bands) with those obtained experimentally have been carried out. Procedure described in work [27] was used for calculations, details are given elsewhere [35]. The final results are summarised in Fig 8. For microstructure with fine carbides (FC) the prediction calculated for cell size $\left(\mathrm{V}_{0}\right)^{1 / 3} \approx 50 \mu \mathrm{m}$ seems to be the quite reasonable. As mentioned above, this is the value corresponding well to average value of cleavage facet(s) initiating fracture. The $90 \%$ probability scatter band (dashed lines) is slightly wider than that designated in Fig. 1a). Contrary, the prediction made for $\left(\mathrm{V}_{0}\right)^{1 / 3} \approx 100 \mu \mathrm{m}$ (results are represented by shadowed area in Fig, 8a) have given unacceptable data. It means practically that value of $V_{0}$ have to be chosen with respect to real fracture micromechanism. For microstructure with coarse carbides (CC) similar findings have been drawn. In this case, the prediction calculated for cell size $\left(\mathrm{V}_{0}\right)^{1 / 3} \approx 100 \mu \mathrm{m}$ seems to be better corresponding to measured values than calculation for $\left(\mathrm{V}_{0}\right)^{1 / 3} \approx 50 \mu \mathrm{m}$. Also in this case the better prediction is reached for cell size corresponding well to real fracture initiation mechanism. 

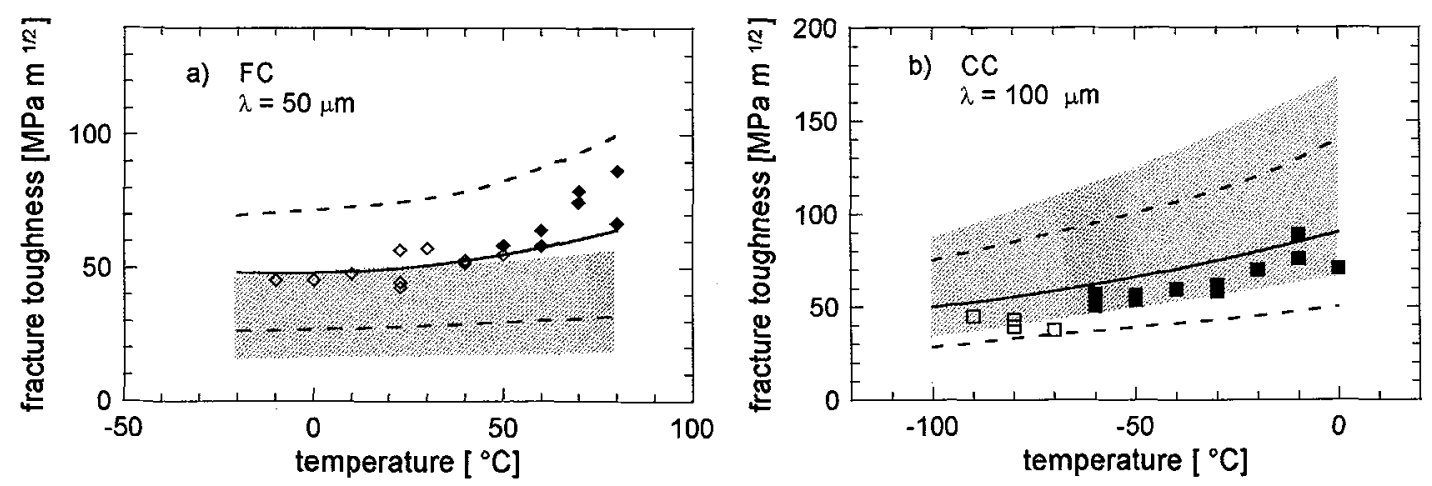

Figure 8. Prediction of fracture toughness - temperature dependence calculated for values of $\left(V_{0}\right)^{1 / 3} \approx$ designated in figures (full and dashed lines) and for evidently wrong values of $\left(\mathrm{V}_{0}\right)^{1 / 3}$ - in case of $\mathrm{FC}\left(\mathrm{V}_{0}\right)^{1 / 3} \approx 100, \mu \mathrm{m}$ in case of $\mathrm{CC}\left(\mathrm{V}_{0}\right)^{1 / 3} \approx 50 \mu \mathrm{m}$.

Local parameters for CVN bend specimen the tests were compared with results generated for the axisymmetric notched specimens. The test of notched tensile specimen were carried out at the same temperatures at which the static bend tests of CVN specimen occurred, i.e. at condition corresponding to pure cleavage fracture. The results of calculation of Weibull parameters (Tab. 7) have shown the small difference of $\sigma_{u}$ values obtained from those evaluated by means of Charpy specimens (compare tables 6 and 7). Nevertheless, the conclusion concerning the intrinsic resistance to cleavage fracture of microstructures investigated is consistent with that resulting from Charpy specimens. The drop of $\sigma_{\mathfrak{u}}$ with increasing cell size is fully comparable however.

Table: 7 Local parameters calculated for various cell sizes and for notched tensile specimen

\begin{tabular}{|c|c|c|c|c|c|c|c|c|}
\hline \multirow{2}{*}{$\begin{array}{c}\text { micro- } \\
\text { structure }\end{array}$} & \multicolumn{2}{|c|}{$\lambda=50 \mu \mathrm{m}$} & \multicolumn{2}{c|}{$\lambda=75 \mu \mathrm{m}$} & \multicolumn{2}{c|}{$\lambda=100 \mu \mathrm{m}$} & \multicolumn{2}{c|}{$\lambda=125 \mu \mathrm{m}$} \\
\cline { 2 - 9 } & $\mathrm{m}$ & $\sigma_{\mathrm{u}}[\mathrm{MPa}]$ & $\mathrm{m}$ & $\sigma_{\mathrm{u}}[\mathrm{MPa}]$ & $\mathrm{m}$ & $\sigma_{\mathrm{u}}[\mathrm{MPa}]$ & $\mathrm{m}$ & $\sigma_{\mathrm{u}}[\mathrm{MPa}]$ \\
\hline $\mathrm{FC}$ & 9.10 & 4070 & 9.20 & 3500 & 9.3 & 3230 & - & - \\
\hline $\mathrm{CC}$ & 10.1 & 3120 & - & - & 10.25 & 2450 & 10.4 & 2340 \\
\hline
\end{tabular}

To explain in more details the differences between both geometries for determining the local parameters higher number of tests are necessary now in progress. Having obtained further results from axisymmetric cylindrical samples the prediction of fracture toughness scatter band versus temperature for both microstructures and geometries using Weibull local parameters will be finished.

\section{CONCLUSION}

Accepting the Beremin approach to the analysis of local criteria for cleavage fracture the location and shape parameters were calculated using FEM for CVN bend specimens. For two microstructures investigated the location parameters were related to cleavage fracture stresses determined according to deterministic approach. The local material parameters $\sigma_{u}$ and $m$ are well susceptible to explain differences between the particular microstructures. The ferrite with fine carbides exhibits higher values of stress $\sigma_{\mathrm{u}}$ when compared to the ferrite with coarse carbides, this is in consistency with the relation of cleavage fracture stresses $\sigma_{\mathrm{CF}}$. Location parameter $\sigma_{\mathrm{u}}$ is a strong function of cell size $\mathrm{V}_{0}$ chosen. The drop in $\sigma_{\mathrm{u}}$ with increasing $\mathrm{V}_{0}$ is approximately the same for both microstructures. Taking into account the values of $\sigma_{u}$ and comparing the Weibull shape parameter the microstructure with coarse carbides exhibits higher values of this parameter corresponding to the smaller scatter and to the higher probability of cleavage failure initiation in the elementary cells than the microstructure with fine carbides. This enhancement of cleavage probability in cell volume corresponds well to carbide induced cleavage due to 
higher carbide thickness. Prediction calculated for cell sizes close to average diameter of real initiation sites have given data fully comparable with experimental values. Fractographic analysis supported well this observation, the changes in cleavage micromechanism and macroscopic appearance of fracture surface were described. From comparison of local parameters determined using notched tensile specimen with those obtained using CVN bend specimen followed certain differences, although basic quantitave relation between model microstructures was kept.

\section{Acknowledgments}

Support to this research by Grant Agency of the Czech Republic under grant number 106/96/0821 is gratefully acknowledged.

\section{References}

[ 1] Knott J.F., J. Iron \& Steel Inst. Vol. 204 (1966) 104-111.

[2] Lin T., Evans A.G., Ritchie R.O., Met. Trans. 18A (1987) 641-651.

[3] Martín-Meizoso A. , Acta Metall. Mater. Vol. 42 (1994) 2057-2068.

[ 4] Ritchie R.O., Knott J.F., Rice J.R., J. Mech. Phys. Solids Vol. 21 (1973) 395-410.

[ 5] Griffiths J.R., Owen W.S., J. Mech. Phys. Solids Vol 19 (1971) 419-431.

[6] Holzmann M., Man J., J. Iron \& Steel Inst. Vol. 209 (1971) 836-838.

[ 7] Bowen P. , Acta Metal., Vol. 34 (1986) 677-684.

[ 8] Smith E., In Proc. of Conf. on Physical Basis of Yield and Fracture Inst. of Physics, Oxford, UK (1966) 36-45.

[ 9] Petch N.J. Acta Metal. 34 (1986) 1387-1394.

[10] Naylor J. P. Met. Trans. 10 (1979) 861-872.

[11] Brozzo P.: Metal Science, 11 (1977) 123-128.

[12] Curry D. A. Metal Science (1978) 511-515.

[13] Sevillano J.G. Acta Metall. 34 (1986) 1473-1484.

[14] Curry D., Knott J.F., Met. Sci. Vol. 13 (1979) 341-345.

[15] Curry D., Met. Sci. Vol. 14 (1980) 78-82.

[16] Strnadel B. Modelling of Fracture Events in Structural Steels (thesis for Doctor of science degree) Technical University of Ostrava, 1995.

[17] Xu X.X. et al., Mat. Sci. \& Techn. Vol. 5 (1989) 913-917.

[18] Chen J.H. Wang G.Z., Wang Z., Zhu L., Gao Y.Y., Met. Trans. 22A (1991) 2287-2296.

[19] Bowen P., Knott J.F.: Met. Sci. 18 (1984) 225-231.

[20] Gerberich W.W., Chen S.H., Lee C.S., Livne T.: Met. Trans. Vol. 18A (1987) 1861-1875.

[21] Beremin F. M., Metall. Transactions Vol. 14A (1983) 2277-2287.

[22] Sainte-Catherine C.: Draft procedure to measure and calculate local fracture criteria on notched tensile specimens, Meeting of ESIS TC1, Elastic Plastic Fracture Mechanics, Appendix 1, (1995).

[23] Landes J.D., Fatigue Fract. Engng. Mater. Struct. Vol. 16 (1993) 1161-1174.

[24] Fontaine A., Maas E., In The Fracture Mechanics of Welds, EGF Pub. 2, Eds. J.G. Blauel \& K.H. Schwalbe (1987) 43-58.

[25] Besson J., Devillers-Guerville, D., Pineau A., Joly P. In Proc. of Workshop „Mechanical Behaviour of Damaged Solids“, Fontainebleau, (1995).

[26] Wallin L K.: Optimized analysis of brittle fracture toughness data, Meeting of ESIS TC1, Elastic Plastic Fracture Mechanics, P10, (1995).

[27] Lidbury D. P. G., Sherry A.H., Beadsmore D. et al., Application of local approach to predict cleavage and ductile fracture, TAGSI Symp. Advances in Fracture Mechanics, (1996).

[28] Wiesner C. S. Investigation into temperature and specimen geometry dependence of the local approach parameters of a structural steel, Meeting of ESIS TC1, Elastic Plastic Fracture Mechanics, P2, (1995).

[29] Dlouhý I., Holzmann M. - The role of packet size in the upper nose temper embrittlement phenomena in CrMo and CrMoV steels, Subm. to Mat. Sci. Techn. (1995).

[30] Válka L., Micromechanistic aspects of brittle fracture initiation ( $\mathrm{PhD}$ thesis), Inst. of Phys. of Materials, 996.

[31] Kozák V., Malý J. Engineering Mechanics 3 (1993) 46 -52.

[32] Holzmann M., Dlouhý I., Válka L. Instrumented impact testing as a method of cleavage fracture stress determination, Proc. of the ECF 11 (1996).

[33] Holzmann M., Vlach B., Man J., Krejčí J.,Steel research 66 (1995) 264-271.

[34] Holzmann M., Vlach B., Man. J., Metallic Materials 26 (1988) 294-304.

[35] Kozák L., Dlouhý I., Proc. of Int. Conf. Numerical methods in Fracture Mechanics, Stará Lesná, 1996. 